\title{
Simultaneous Determination of Plasma Cortisol by High Performance Liquid Chromatography and Radioimmunoassay Methods in Fish
}

\author{
J. BLAHOVÁ, R. DOBŠÍKOVÁ, Z. SVOBODOVÁ, P. KALÁB \\ University of Veterinary and Pharmaceutical Sciences Brno, Czech Republic
}

Received March 15, 2006

Accepted October 20, 2006

\begin{abstract}
Blahová J., R. Dobšíková, Z. Svobodová, P. Kaláb: Simultaneous Determination of Plasma Cortisol by High Performance Liquid Chromatography and Radioimmunoassay Methods in Fish. Acta Vet Brno 76, 2007: 59-64.

The aim of the study was to compare the sensitivity of High Performance Liquid Chromatography (HPLC) and Radioimmunoassay (RIA) analytical methods in the determination of blood plasma cortisol level of common carp (Cyprinus carpio L.). Cortisol, the most potent glucocorticoid, is widely used as an indicator of stress. The monitoring of plasma cortisol concentration was performed during the test focused on stress response caused by handling and long-distance transport of common carp. The samples were collected before, during and after transport.

The correlation between blood cortisol level in fish measured by HPLC and RIA was determined using 66 samples. The correlation was HPLC $=0.9454$ RIA +0.40676 and correlation coefficient was 0.815 . From the presented results it can be concluded that both methods (RIA and HPLC) can be used for the determination of plasma (serum) cortisol level.
\end{abstract}

Transport, Cyprinus carpio L., stress

Cortisol is the most potent and abundant glucocorticoid secreted by the outer cortex of the adrenal gland. Its secretion is stimulated by the adrenocorticotrophic hormone (ACTH) produced in the pituitary in response to corticotropin-releasing hormone (CRH). In mammals, $90 \%$ of the secreted cortisol in circulation is bound to plasma proteins, mainly to cortisol-binding globulin (CGB). The rest of cortisol circulates in an unboud form, i.e. the physiological active form. In fish, cortisol is bound to plasma proteins in considerably lower amounts. Caldwell et al. (1991) cites that only $48.2 \%, 16 \%$ and $19 \%$ of cortisol is bound to plasma proteins in adult females, adult males and juvenile individuals of rainbow trout, respectively. Plasma cortisol levels are known to cycle diurnally and to change according to season. During the day the highest concentration is measured in the morning and then the level declines throughout the day (Kaneko 1997; McLeese et al. 1994; Zima et al. 2002).

Plasma cortisol level is widely used as an indicator of stress (Möstl and Palme 2002). Stress is commonly defined as a state or condition in which the homeostasis of an individual is disturbed as a result of the actions of external or internal stimuli, termed stressors. The stressors elicit changes in the animal's physiological state, which is interpreted as the stress response (Gregory and Wood 1999). In response to a stressful event, the hypothalamic portion of the brain stimulates the release of ACTH. ACTH circulates into the anterior kidney, where it stimulates the interrenal cells to produce cortisol and other corticosteroid hormones. Cortisol then plays an important role in mobilizing fuels such as glucose, lipids, and fatty acids for the maintenance of homeostasis and exerts direct and indirect effects on intermediary metabolism, particularly in response to stress. The fish are exposed to stressors in nature, as well as in artificial conditions such as in aquaculture, or in the laboratory. The increasing contamination of bodies of natural freshwater and marine ecosystem worldwide by anthropogenic substances is one

Address for correspondence:

Ing. Jana Blahová

University of Veterinary and Pharmaceutical Sciences

Palackého 1-3

61242 Brno, Czech Republic
Phone: +420541562785

Fax: + 420541562790

E-mail: blahovaj@vfu.cz

http://www.vfu.cz/acta-vet/actavet.htm 
source of environmental stressor. Various stressors, such as grading, handling, transportation and vaccination, are necessary components of modern intensive fish culture ( $\mathrm{S}$ v oboda 2001; Kubilay and Ulokoy 2002; Jelínek and Koudela 2003).

Plasma cortisol level can be measured by commercial radioimmunoassay (RIA), enzymelinked immunosorbent assay (ELISA) or chromatographic methods (HPLC or GC). All three methods of analysis have their advantages and disadvantages. The aim of the study was to determine the most appropriate method. The commercial availability of sensitive and specific antisera for cortisol has made RIA the method of choice in most laboratories (Ruder et al. 1972; Drastichová et al. 2004). However, the advantage of using ELISA is that it does not require the use of any radioactive reagent, and therefore it is safer and more economical than standard RIA. Chromatographic methods might be more specific and accurate analytical methods, but they are also considerably more time consuming, and require much more complicated instrumentation (Nozaki 2001; Bartels et al. 2003; Dobšíková et al. 2006). HPLC with UV, fluorescence or mass spectrometry detection is the most often used for cortisol determination. The simplest and most often used detection method is UV detection (wavelength cca $250 \mathrm{~nm}$ ). The HPLC/UV disadvantage is its lower sensitivity in comparison to other detection methods. Mass spectrometry is more sensitive but too expensive and not available in all laboratories. The use of fluorescence detection is subjected to conversion of cortisol to fluorescent substance. The conversion is enabled by using various derivatisation reagents (9-anthroylnitrile, dansylhydrazine, sulphuric acid with ethanol, etc.). Fluorescence detection methods are limited by precisely controlled reaction conditions and the instability of the fluorescent product (Goto et al. 1983; Volin 1995; Shibata et al. 1998; Nozaki 2001). Mass spectrometry detection is the most used GC method for the plasma cortisol determination (Heckmann et al. 2005).

The aim of this study was to compare the sensitivity of HPLC and RIA analytical methods in the evaluation of blood plasma cortisol level of common carp (Cyprinus carpio L.). For HPLC determination of plasma cortisol a chromatographic system Alliance 2695 was used with Photodiode Array Detector 2996 (Waters, USA). For RIA determination of plasma cortisol a Cortisol RIA kit was used (Immunotech Prague; A Beckman Coulter Company).

\section{Materials and Methods}

Sample handling and preparation of plasma

The monitoring of blood plasma cortisol was made during the test focused on the stress load by handling and transport of common carp. The samples were collected before, during and after regular transport (April 29, 2005) of fish from storage ponds at a commercial fish farm in Hluboká nad Vltavou via Brno (Czech Republic) to a fishpond in Bohelov (Slovakia), 12 hours in total. Carp were held in a freshwater flow-through storage pond for three days prior to transportation, and then transferred to $2.2 \mathrm{~m}^{3}$ transport tanks (loading density of $364 \mathrm{~kg}$ body weight $\cdot \mathrm{m}^{-3}$ ). In total, 66 individuals of common carp were tested. The blood samples were withdrawn by cardiocenthesis and collected in glass tubes containing heparin and centrifuged at 3,000 rpm for $10 \mathrm{~min}$, then plasma was separated (Svobodová et al. 1991). The plasma samples were kept frozen at $-80{ }^{\circ} \mathrm{C}$ in Eppendorf test-tubes until analysis.

Chromatographic conditions and sample pre-treatment

For plasma sample preparation, the SPE (solid phase extraction) was used before HPLC analysis. Cortisol was extracted using SPEC C18AR columns ( $3 \mathrm{ml}, 30 \mathrm{mg}$, Varian Inc.), which had been activated with $1 \mathrm{ml}$ of methanol (Merck) followed by $1 \mathrm{ml}$ of deionized water. After application of samples $(1 \mathrm{ml})$, the cartridges were washed with $1 \mathrm{ml}$ deionized water followed by $1 \mathrm{ml}$ of $20 \%$ methanol in deionized water. Then the cartridges were air-dried under reduced pressure for $5 \mathrm{~min}$. The analyte was eluated with $1 \mathrm{ml}$ of acetonitrile (Merck). $20 \mu \mathrm{l}$ of the eluted sample was then injected into the HPLC system. The SPE was used for standard preparation procedure, too.

Stock calibration solution of cortisol (Sigma-Aldrich) was prepared by dissolving $4 \mathrm{mg}$ pure substance in 200 $\mathrm{ml}$ of $60 \%$ acetonitrile in deionized water. The solution was stable for at least two months when stored at $4{ }^{\circ} \mathrm{C}$. Standard solutions were obtained by diluting stock solution with deionized water before use.

The HPLC system was equipped with a Waters Model 2695 Alliance Separation Module and Waters 2996 Photodiode Array Detector. Chromatographic separation was achieved on a Polaris C18-A column $(3 \mu, 150 \times 4.6$ $\mathrm{mm}$, Varian Inc.). The guard column was a MetaGuard Polaris C18-A $(5 \mu, 10 \times 4.6 \mathrm{~mm}$, Varian Inc. $)$ The mobile phase was pumped at a flow rate of $1 \mathrm{ml} / \mathrm{min}$ and consisted of acetonitrile $(60 \%)$ and water $(40 \%)$ at a temperature 
of $35^{\circ} \mathrm{C}$. The mobile phase was degassed ultrasonically before use. Detection was done by UV absorption at 243 $\mathrm{nm}$. Data recording was carried out using Waters Empower software.

\section{Conditions of RIA determination}

A cortisol RIA kit Immunotech Prague (A Beckman Coulter Company) was used for RIA determination of plasma cortisol. The RIA kit is intended for the quantitative direct (without extraction of the sample) determination of cortisol concetration in human serum, plasma and urine. The urine samples may be analyzed both directly and after extraction.

Samples and standards were incubated in monoclonal antibody - coated tubes with ${ }^{125}$ I-labelled cortisol tracer (50 $\mathrm{ml}$ sample or standard and $500 \mathrm{ml}$ of tracer). Each sample and standard was pipeted into two tubes. After incubation (1 hour, horizontal shaking - $400 \mathrm{rpm}$ ) the liquid contents of the tubes were aspirated to the waste and the radioactivity bound to the antibody was measured by JNG 403 (multichannel gamma counter for RIA). Concentration of samples was obtained from the calibration curve. The samples were analysed using two kits in two analyses.

\section{Statistical analysis}

Values of blood plasma cortisol level detected by RIA and HPLC methods showed lognormal division, therefore they were transformed using natural logarithm before further statistic processing. The adjusted data were subject to regression analysis. To find correlation between values aquired using these two methods, Pearson correlation coeffiecient was used. Statistical processing was performed by Statistica 7.1 programme (StatSoft Inc. 2005).

\section{Results}

\section{Chromatographic analysis}

The calibration curve for peak areas vs. quantity of cortisol was linear from 40 to $1000 \mathrm{ng} \cdot \mathrm{ml}^{-1}$. The limit of quantification (signal-to-noise ratio $=10$ ) was $30 \mathrm{ng} \cdot \mathrm{ml}^{-1}$. The typical chromatogram of cortisol in blood plasma of carp is shown in Fig. 1. The results ranged from $100.35 \mathrm{ng} \cdot \mathrm{ml}^{-1}$ to $992.44 \mathrm{ng} \cdot \mathrm{ml}^{-1}$. Cortisol elutes as a sharp symmetrical peak at about $2.2 \mathrm{~min}$.

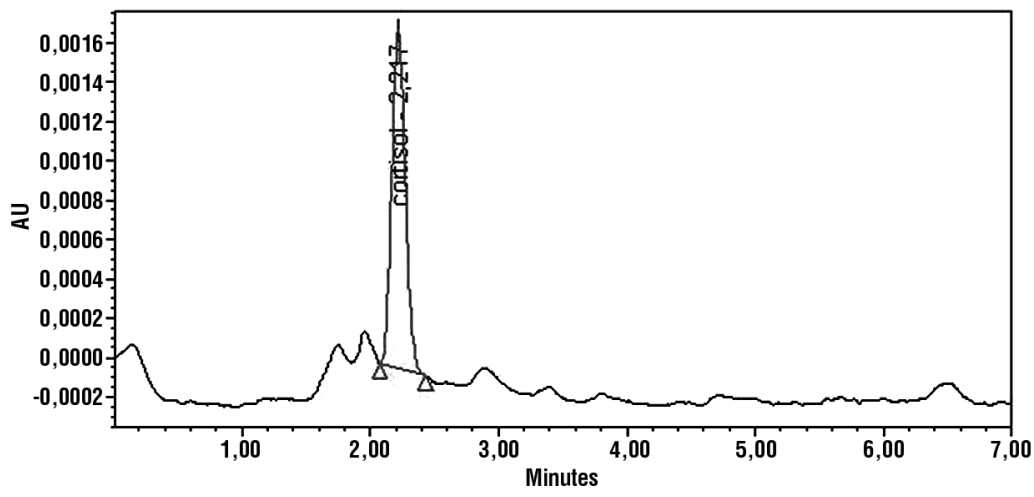

Fig. 1. Chromatogram of blood plasma cortisol from carp $\left(257.11 \mathrm{ng} \cdot \mathrm{ml}^{-1}\right)$

\section{RIA analysis}

The calibration curve was made in a range from 3.64 to $725 \mathrm{ng} \cdot \mathrm{ml}^{-1}$. The method was linear in the range of calibration curve. The limit of quantitation was determined $3.64 \mathrm{ng} \cdot \mathrm{ml}^{-1}$ - the lowest value of calibration curve. The range of results was $99.64 \mathrm{ng} \cdot \mathrm{ml}^{-1}$ to $760.73 \mathrm{ng} \cdot \mathrm{ml}^{-1}$. Variation coefficients of replicates were in the range $0.27-13.9 \%$, average $3.5 \pm 3.1 \%$.

\section{Correlation between methods}

Cortisol values showed lognormal division; therefore they were transformed using natural logarithm before further statistic processing. Plasma cortisol correlation between the RIA and HPLC assay was found to be HPLC $=0.9454$ RIA +0.40676 . Correlation coeficient of 


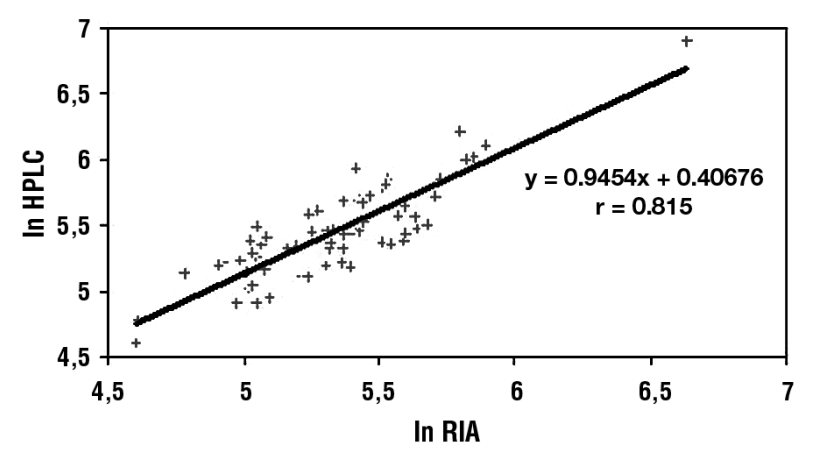

Fig. 2. Correlation between results of plasma cortisol by RIA and HPLC. Values given in natural logarithm

the assys was found to be 0.815 (significance at $p<0.001$ ) (Fig. 2). The methods showed comparable results within the measurement spectrum.

\section{Discussion}

Measurement of plasma cortisol level is often used as an indicator of stress. The aim of the study was to compare sensitivity of two widely applied methods (RIA and HPLC) used for the quantification of blood plasma cortisol level. The study was made during the test focused on stress response of common carp (Cyprinus carpio L.) subjected to pre-transport manipulation and long-distance transportation. From the results, it can be suggested that both methods used are suitable for the measurement of plasma cortisol level. The correlation between cortisol levels was found to be HPLC $=0.9454$ RIA +0.40676 , and subsequently the correlation coefficient was found to be 0.815 (significance at $p<0.001$ ). The methods used showed comparable results within the measurement spectrum. In addition, the results of our measurement are in a good agreement with the results of several studies.

Turpeinen et al. (1997) present the results of comparison of HPLC and RIA assays used for the measurement of urinary free cortisol. The correlation between the methods was determined with 88 patient samples and was found to be HPLC $=0.50505$ RIA +11.36363 ; the correlation coefficient was 0.78 . The results obtained by HPLC averaged $40 \%$ of the RIA values. RIA higher concentration was probably due to possible cross-reactivity of substances.

Loche et al. (1984) analyzed blood serum cortisol from a patient undergoing laboratory and clinical evaluation for various endocrine diseases. In more than 50 samples in which cortisol was measured by both RIA and HPLC, no statistically significant difference was found between the two methods, as calculated by the paired $t$ test $(p=0.88666)$ or the one-way ANOVA $(p>0.25)$. The differences in results may be caused by non-specificity of RIA, because anti-cortisol antibodies may cross-react to varying degrees with other steroids, such as cortisone, 11-deoxycortisol, 17-hydroxyprogesterone, corticosterone, prednisone, prednisolone and deoxycorticosterone.

Meijer et al. (2002) confirm a negative attribute of RIA: cross-reactivity. In the study, the measurement of cortisol level using RIA and HPLC assay in patients given prednisolone (30mg/day) proved that serum cortisol concentration by HPLC assay was by $38 \%$ higher in comparison with RIA. As expected, the difference between the cortisol levels measured by RIA and HPLC increased with higher serum prednisolone concentrations. 


\section{Porovnání metody HPLC a RIA pro stanovení plazmatického kortizolu u ryb}

Cílem této práce bylo porovnání citlivosti analytických metod - HPLC a RIA využité pro stanovení hladiny plazmatického kortizolu u kapra obecného (Cyprinus carpio L.). Kortizol, nejúčinnější glukokortikoid, se často použivá jako indikátor stresu. Monitorování plazmatické koncentrace kortizolu bylo provedeno v průběhu sledování stresového zatížení kapra obecného při transportu. Vzorky byly odebírány před, v průběhu a po ukončení transportu.

Korelace mezi hodnotami kortizolu v plazmě získanými metodami HPLC a RIA byla provedenu u 66 vzorků. Nalezená korelace byla HPLC = 0,9454 RIA + 0,40676 a hodnota korelačního koeficientu byla 0,815 . Z uvedených výsledků je zřejmé, že obě metody (RIA a HPLC) mohou být použity pro stanovení hladiny kortisolu v plazmě (séru).

\section{Acknowledgements}

This research was supported by the Ministry of Education, Youth and Sports of the Czech Republic (MSMT 6215712402).

\section{References}

BARTELS M, VAN DEN BERG M, SLUYTER F, BOOMSMA DI, DE GEUS EJC 2003: Heritability of cortisol levels: review and simultaneous analysis of twin studies. Psychoneuroendocrinology 28: 121-137

CALDWELL CA, KATTESH HG, STRANGE RJ 1991: Distribution of cortisol among its free and protein-bound fractions in rainbow trout (Oncorhynchus mykiss): evidence of control by sexual maturation. Comp Biochem Physiol PT A 99: 593-595

DOBŠ́KOVÁ R, SVOBODOVÁ Z, BLAHOVÁ J, MODRÁ H, VELÍŠEK J (2006): Stress response to long distance transportation of common carp, Cyprinus carpio L. Acta Vet Brno 75: 437-448

DRASTICHOVÁ J, SVOBODOVÁZ, LUSKOVÁ V, ČELECHOVSKÁ O, KALÁB P (2004): Effect of cadmium on blood plasma biochemistry in carp (Cyprinus carpio L.). Bull Environ Contam Toxicol 72: 733-740

GOTO J, SHAMSA F, NAMBARA T 1983: Determination of dexamtehasone and cortisol in serum by highperformance liquid chromatography with fluorescence detection. Jpn J Clin Chem 12: 327-333

GREGORY TR, WOOD CHM 1999: The effects of chronic plasma cortisol elevation on the feeding behaviour, growth, competitive ability, and swimming performance of juvenile rainbow trout. Physiol Biochem Zool 72: 286-295

HECKMANN M, HARTAMANN MF, KAMPSCHULTE B 2005: Cortisol production rates in preterm infants in relation to growth and illness: A noninvasive prospective study using gas chromatography-mass spectrometry. J Clin Endocrinol Metab 90: 5737-5742

JELÍNEK P, KOUDELA K, 2003: Physiology of domestic animals. 1. vydání. MZLU Brno, 414 p. (in Czech).

KANEKO JJ 1997: Clinical Biochemistry of Domestic Animal. $5^{\text {th }}$ Edition. Academic Press, Inc. California, $932 \mathrm{p}$.

KUBILAY A, ULUKOY G 2002: The effects of acute stress on rainbow trout (Oncorhynchus mykiss). Turk J Zool 26: $249-254$

LOCHE S, PORCELLI F, ROSEN M, FEFFER M, STONER E, NEW MI 1984: Clinical applications of the rapid high-performance liquid chromatographic determination of serum cortisol. J Chromatogr 317: 377-382

MCLEESE JM, JOHNSON J, HUNTLEY EM, CLARKE WC, WEISBART M 1994: Seasonal changes in osmoregulation, cortisol, and cortisol receptor activity in the gills of parr/smolt of steelhead trout and steelheadrainbow trout hybrids, Oncorhynchus mykiss. J Fish Biol 28: 525-531

MEIJER RJ, POSTMA DS, KERSTJENS HAM 2002: Conventional RIA underestimates cortisol suppression in the presence of prednisolone. Thorax 57: 374-376

MÖSTL E, PALME R 2002: Hormones as indicators of stress. Domest Anim Endocrinol 23: 67-74

NOZAKI O 2001: Steroid analysis for medical diagnosis. J Chromatogr A 935: 267-278

RUDER HJ, GUY RL, LIPSETT MB 1972: A radioimmunoassay for cortisol in plasma and urine. J Clin Endocrinol 35: 219-224

SHIBATA N, HAYAKAWA T, TAKADA K, HOSHINO N, MINOUCHI T, YAMAJI A 1998: Simultaneous determination of glucocorticoids in plasma or urine by high-performance liquid chromatography with precolumn fluorimetric derivatization by 9-anthroyl nitrile. J Chromatogr B 706: 191-199

SVOBODA M 2001: Stress in fish - review. Bull VÚRH Vodňany 37: 169-191 (in Czech)

SVOBODOVÁ Z, PRAVDA D, PALÁČKOVÁ J 1991: Unified methods of haematological examination of fish. Methods No. 20. Research Institute of Fish Culture and Hydrobiology, Vodňany, 31 p.

TURPEINEN U, MARKKANEN H, VALIMAKI M, STENMAN U 1997: Determination of urinary free cortisol by HPLC. Clin Chem 43: 1386-1391 
VOLIN P 1995: High-performance liquid chromatographic analysis of corticosteroids. J Chromatogr B 671: 319-340

ZIMA T, KAZDA A, PRU゚ŠA R, ŠTERN P 2002: Laboratory diagnostic. 1. vydání. Galén, Praha, 728 p. (in Czech). 